\title{
Brown booby (Sula leucosgaster) envenomation and death caused by toadfish (Porichthys porosissimus) ingestion in Southeastern Brazil
}

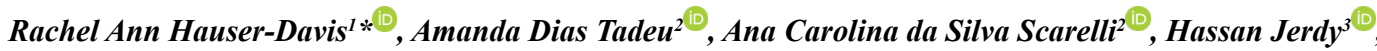

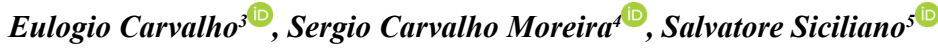 \\ ${ }^{1}$ Instituto Oswaldo Cruz/Fiocruz, Laboratório de Avaliação e Promoção da Saúde Ambiental, Av. Brasil, 4.365, \\ Manguinhos, 21040-360, Rio de Janeiro, RJ, Brasil. \\ ${ }^{2}$ CTA Serviços em Meio Ambiente. Rua Saturnino Rangel Mauro, 283, 29062-030, Vitória, ES, Brasil. \\ ${ }^{3}$ Universidade Estadual do Norte Fluminense "Darcy Ribeiro", Parque Califórnia, 28013-602, Campos dos \\ Goytacazes, RJ, Brasil. \\ ${ }^{4}$ Museu Nacional, UFRJ, Programa de Pós-graduação em Zoologia, Quinta da Boa Vista, 20940-040 São \\ Cristóvão, Rio de Janeiro, RJ, Brasil. \\ ${ }^{5}$ Instituto Oswaldo Cruz/Fiocruz, Laboratório de Biodiversidade, Pavilhão Mourisco, sala 217, Av. Brasil, \\ 4.365, 21040-900, Manguinhos, Rio de Janeiro, RJ, Brasil. \\ *Corresponding author: Rachel Ann Hauser-Davis,e-mail: rachel.hauser.davis@gmail.com
}

HAUSER-DAVIS, R.A., TADEU, A.D., SCARELLI, A.C.S., JERDY, H., CARVALHO, E., MOREIRA, S.C., SICILIANO, S. Brown booby (Sula leucosgaster) envenomation and death caused by toadfish (Porichthys porosissimus) ingestion in Southeastern Brazil. Biota Neotropica 21(2): e20201125 . . https://doi.org/10.1590/16760611-BN-2020-1125

\begin{abstract}
A case report of six brown booby (Sula leucogaster) envenomation following the ingestion of toadfish (Porichthys porosissimus) specimens in Rio de Janeiro, Southeastern Brazil is discussed herein. Several macroand microscopic pathological alterations were observed in the examined brown booby specimens, and rapid envenomation $(<24 \mathrm{~h})$ is suggested due to the digestion stage of the fish found in their gastrointestinal tracts. This is the first report to mention the death of adult and juvenile brown boobies due to envenomation by the toadfish $P$. porosissimus. Further studies assessing the role of discarded fish as a driving force of negative effects on seabirds, such as envenomations, for example, along the southeastern coast of Brazil are recommended.

Keywords: Fatal ingestion; poisonous fish; seabirds; Western Atlantic

\section{Envenenamento e morte de atobás-marrons (Sula leucogaster) causados pela ingestão de magangá-liso (Porichthys porosissimus) no sudeste do Brasil}

\begin{abstract}
Resumo: Um relato de caso sobre o envenenamento de seis indivíduos de atobás-marrons (Sula leucogaster) após a ingestão de espécimes de mangagá-liso (Porichthys porosissimus) no Rio de Janeiro, sudeste do Brasil, é discutido neste estudo. Diversas alterações patológicas macro e microscópicas foram observadas nos espécimes de atobámarrom examinados, e um envenenamento rápido $(<24 \mathrm{~h})$ é sugerido devido ao estágio de digestão dos peixes encontrados em seus tubos digestórios. Este é o primeiro registro que menciona a morte de indivíduos juvenis e adultos de atobás marrons por envenenamento devido a ingestão do magangá-liso $P$. porosissimus. Novos estudos avaliando o papel dos peixes descartados como uma força motriz dos efeitos negativos sobre as aves marinhas como, por exemplo, envenenamentos, ao longo da costa sudeste do Brasil são recomendados.
\end{abstract}

Palavras-chave: Ingestão fatal; peixes venenosos; aves marinhas; Oeste Atlântico. 


\section{Introduction}

The toadfish, Porichthys porosissimus (Cuvier, 1829) (Teleostei, Batrachoididae) is found in in marine and brackish environment in the Southwest Atlantic, ranging from Espírito Santo, Brazil to eastern Argentina (Floeter et al. 2003, Figueiredo et al. 2002). This species is routinely caught as by-catch, especially through shrimptrawling activities (Vianna et al. 2000)discarded due to their having no commercial va. Typical toadfish are nocturnal and bury themselves in sand or mud in the intertidal zone during the day and inhabit the water column by (Vianna et al. 2000)discarded due to their having no commercial va. Most present corporal bioluminescent photophores on the lateral of the body and head, probably reproductive in nature, and some species, have venomous dorsal spines and are capable of inflicting serious injuries (Cormier et al. 1967, Greenfield et al. 2008).

Among toadfish, Porichthys porosissimus has been recently proven venomous after much discussion in the literature, although only one study on envenoming by this species is available in the literature, regarding two human cases (Lopes-Ferreira et al. 2014). No reports concerning wildlife envenomation have been reported to date.

In this context, this study consists in a case report of the death of six brown booby (Sula leucogaster) individuals following the ingestion of this venomous toadfish in Rio de Janeiro, Southeastern Brazil. Evidence of Brown booby tissue alterations are discussed.

\section{Material and methods}

The individuals in the present study were found dead on beaches in the Região dos Lagos area, on the coast of the state of Rio de Janeiro, through the Campos Basin Beaches Monitoring Project. The cases were detected in July and August 2019, in the municipalities of Arraial do Cabo, Cabo Frio and Armação dos Búzios (Figure 1). The carcasses were classified as "fresh" or "moderately fresh" (Van Franeker 2004) and were processed and necropsied at the Araruama Rehabilitation and Depetrolization Center.

Carcass weights were determined using a digital scale. Total length measurements were performed using a tape measure. Sexing was determined by means of sexual dimorphism, represented by the physical characteristics and plumage present in adults, and by the gonads in the juvenile individual (Schreiber \& Norton 2002).
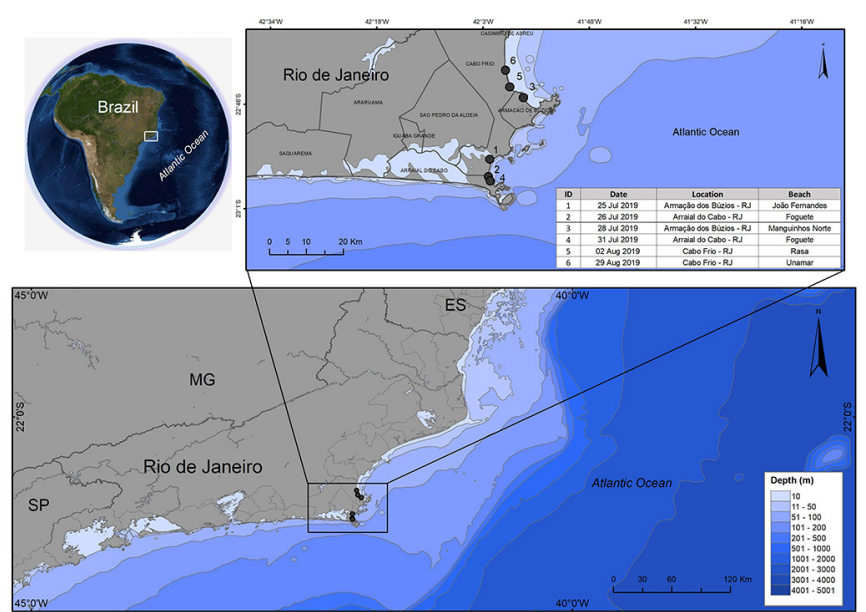

Figure 1. Map indicating the locations of the Brown Booby samplings, Rio de Janeiro, Southeastern Brazil.
The necroscopic exams were performed according to Work (2000). The organs were individually analyzed, and macroscopic changes were described according to the findings, categorized as musculoskeletal, respiratory, cardiovascular, digestive, urinary, reproductive, hemolymphatic, endocrine and nervous system alterations. All information was recorded by photographs, and autopsy reports were completed. Organ samples classified as "fresh" were collected for histopathological evaluations. The samples were first fixed in $10 \%$ neutral buffered formaldehyde for at least 48 hours and subsequently sent to the Animal Morphology and Pathology Laboratory at the Darcy Ribeiro Norte Fluminense State University (UENF), cleaved and taken to a tissue processor (Leica ASP300S) for dehydration, clarification, paraffin impregnation and subsequent block inclusion. After the inclusion process, serial $5 \mu \mathrm{m}$ slices were obtained and stained with hematoxylin and eosin (HE). An optical Leica DM4B microscope (Leica microsystem CMS GmbH, Wetzlar) was used for the microscopic analysis and photomicrographs.

Toadfish specimens found in the digestive tract of the brown boobies were preserved in alcohol following necropsies. Identification was confirmed as $P$. porosissimus after comparison with specimens deposited at the Ichthyological Section of the Museu Nacional/UFRJ. The specimens corroborate previous descriptions for the species (Fishbase 2019, Nakamura et al. 1986, Figueiredo \& Menezes 1980) namely scaleless, exhibiting four lateral lines and displaying two dorsal spines, between 34-36 dorsal soft rays, no anal spines, and 33 anal soft rays. The upper side of the specimens' body was greyish brown, silvery on the side and yellowish on the belly, containing seven dark broad bands on the upper portion of body. The tips of each fin were blackish, dark blotches were noted on the fin membrane of the dorsal and pectoral fins and the pelvic fin was yellowish. Two specimens are now stored at the Biodiveristy Collection (Coleção de Biodiversidade), IOC/Fiocruz under numbers "IOC/Peixes 069" and "IOC/Peixes 070".

\section{Results and discussion}

The Brown booby (Sula leucogaster) inhabits tropical and subtropical regions and breeds along the Brazilian coast (Cunha et al. 2012). When juvenile, this species travels up to $2,000 \mathrm{~km}$ from their hatching site, and after approximately three years return to their original colonies to breed (Nelson 1978, Baumgarten 2003). This species is considered a top predator, foraging primarily on fish and squid residing near their breeding colonies (Alves et al. 2004, Coelho et al. 2004).

From February to November 2019, a total of 91 brown booby specimens were necropsied at the Araruama Rehabilitation Center. A total of 43 individuals died during treatment and 48 were already found dead. Of this total, six presented envenomation by $P$. porosissimus (6.6\%). Of the six envenomated examined specimens, five were adults (three females and two males) and one juvenile (male). Females weighed 1.0-1.2 $\mathrm{kg}(1.1 \mathrm{~kg} \pm 0.1)$, averaging $75.97 \mathrm{~cm}$ in total length, and males weighed $0.8-1.1 \mathrm{~kg}(0.93 \mathrm{~kg}$ $\pm 0,15$ ), with an average total length of $76.9 \mathrm{~cm}$.

Figure 2 exhibits a $P$. porosissimus specimen observed in the gastroesophageal lumen of a brown booby specimen, and different histopathological brown booby alterations.

Macroscopic findings were observed in the cutaneous, respiratory, and digestive systems. Of the six individuals, three presented severe subcutaneous hemorrhage in the cervical region, severe esophageal 
congestion, and hemorrhagic cavitary effusion in the celomatic cavity. The other specimen presented hemorrhagic fluid, over-hyperemic mucosa, and areas of mild edema in the esophageal and gastric mucosae. All six necropsied brown boobies with such lesions had one or more $P$. porosissimus specimens in the gastrointestinal tract, and no piercingcutting lesions were detected. In two specimens, toadfish were found

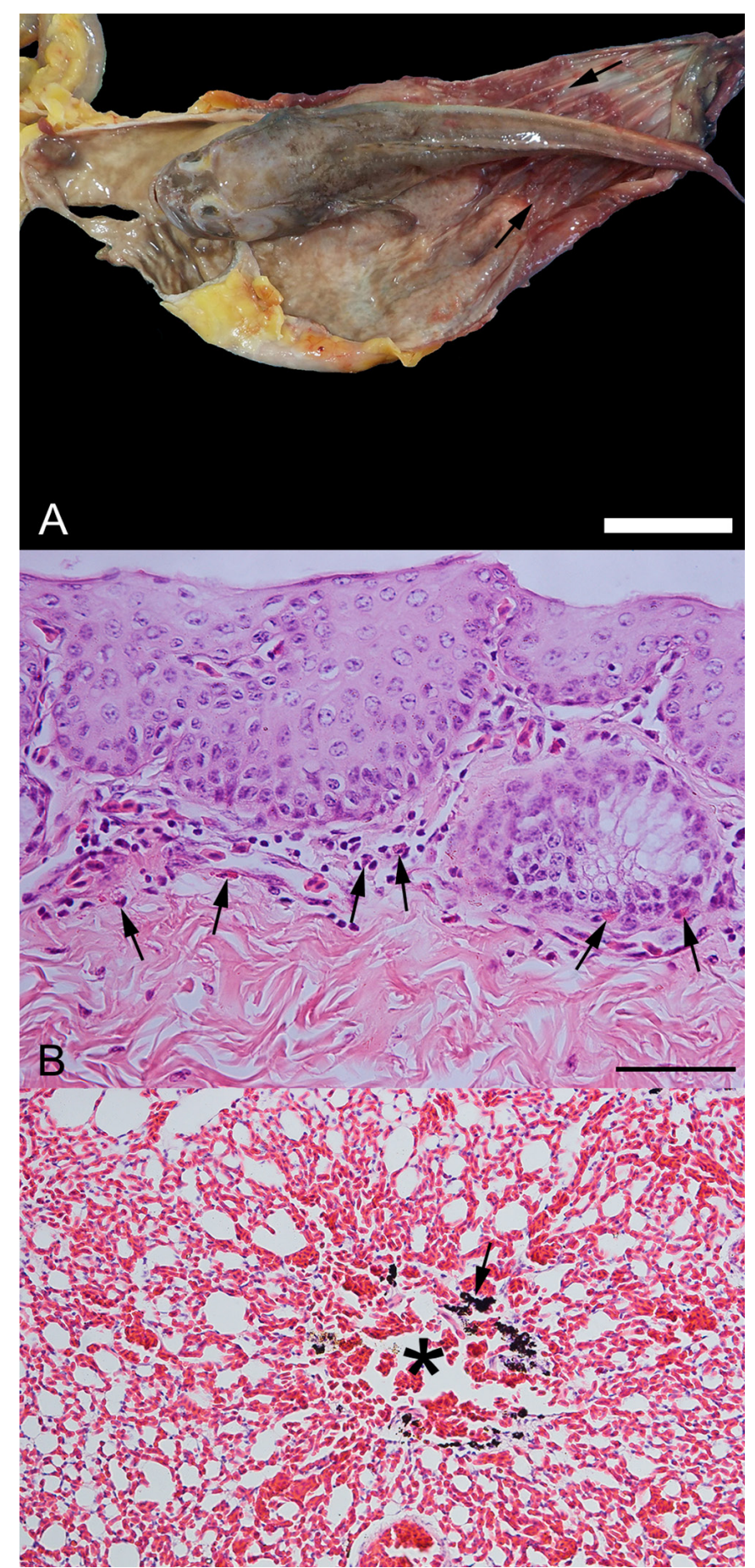

Figure 2. (A) P. porosissimus in the gastroesophageal lumen. Note the esophagitis associated with hemorrhagic exudate (arrow); (B) Slight heterophilic (arrow) inflammatory infiltrate, randomly distributed in the esophageal lamina-propria; (C) Severe parabronchial hemorrhage (asterisk) and diffuse congestion. Mild macrophages that contain a fine black pigment (carbon). only in the stomach and, in the others, in the esophagus and stomach. All individuals presented hemorrhage and severe pulmonary congestion.

Microscopically, a fibrinemorrhagic exudate over the esophageal mucosa was observed, as well as a slight heterophilic inflammatory infiltrate randomly distributed in its own lamina, associated with diffusely ectatic blood vessels, markedly and diffusely congested in the esophageal submucosa. Pulmonary blood capillaries filled with blood, markedly ectatic associated with marked multifocal parabronchial hematic overflow, a diffuse marked interstitial edematous accumulation and moderate to diffuse edematous edematous edema were also observed. Aerial capillaries were multifocal and moderately collapsed.

Due to the decomposition stage and digestion process of the fish, accurate measurements could not be performed. However, all specimens were approximately $10 \mathrm{~cm}$ in total length, and possibly young specimens, given that the largest $P$. porosissimus recorded in the literature measured $32 \mathrm{~cm}$ (Figueiredo \& Menezes 1978).

Marine fish present an enormous diversity and complexity of venoms and poisons, such as in the Scorpaenidae, Tetraodontidae, Dasyatidae and Batrachoididae families (Smith \& Wheeler 2006). The absence of a venom gland attached to $P$. porosissimus dorsal and opercular spines, and the fact that the spines are solid and not hollow has led researchers to classify this species as non-venomous (LopesFerreira et al. 2014). However, the presence of a pectoral axillary gland (Collette \& Russo 1981), glandular tissue on the pectoral fin (Walker \& Rosenblatt 1988) and two curved opercular spines containing a yellow mass, probably the venom glandular tissue (Lane 1967), have indicated probable venomous status. This was confirmed in a study carried out in 2014, regarding two human cases and laboratory mice assessments (Lopes-Ferreira et al. 2014).

Mice exposed to $P$. porosissimus spine extract displayed edematogenic and nociceptive responses, the former indicating severe inflammatory activity, through classical cellular recruitment initiated by neutrophils followed by macrophages and increased leukocyte rolling, with a slightly increase in adherent cells to the endothelium, while nociception induced during the inflammatory period (15-40 $\mathrm{min}$ ) was associated with the augmented rolling and adhesion of leukocytes to the endothelium (Lopes-Ferreira et al. 2014). Exposure to P. porosissimus spine extracts also decreased the blood flow and caliber of vessels participating in microcirculation (Lopes-Ferreira et al. 2014). These edematogenic and nociceptive responses and organ alterations are similar to inflammatory responses induced by other venomous fish, such as other Batrachoididae species like T. nattereri and T. maculosa, Potamotrygonidae freshwater stingrays and Ariidae marine catfish (Magalhães et al. 2006, Monteiro dos Santos et al. 2011, Junqueira et al. 2007, Sosa-Rosales et al. 2005)local, and intense pain, soft tissue edema, and a variable extent of bleeding. The present study was carried out in order to describe the principal biological and some biochemical properties of the Brazilian Potamotrygon fish venoms (Potamotrygon cf. scobina and P. gr. orbignyi.

The only account in the literature regarding $P$. porosissimus spine puncture effects indicates intense and continuous pain, lasting about 2 hours (Lopes-Ferreira, et al., 2014), and a previous citation about this venom indicates arteriolar constriction, although no further details are given (Lane 1967). One study attributed the death of five procellariiform species - Atlantic Yellow-nosed Albatross (Thalassarche chlororhynchos), Cory's Shearwater (Calonectris diomedea), Sooty 
Shearwater (Ardenna grisea), Great Shearwater (Ardenna gravis) and Manx Shearwater (Puffinus puffinus), in southern Brazil to the ingestion of $P$. porosissimus and subsequent suffocation (Benemann et al. 2016)we recorded five procellariiform species - Atlantic Yellow-nosed Albatross (Thalassarche chlororhynchos. The authors only briefly mention that the potential effect of $P$. porosissimus toxins might have contributed to the evaluated seabird deaths, and it is important to note that they observed only 22 cases during 6 years of surveys (63 surveys).

In the present study, envenomation by $P$. porosissimus through spine punctures was observed in six brown booby carcasses found on the eastern coast of Rio de Janeiro state, Brazil. The pathological changes detected in the examined specimens are in accordance with the findings by Lopes-Ferreira (2014), suggesting that the effect of the poison in contact with the bird's gastric mucosa resulted in negative flight and fishing activity effects, possibly causing trauma, consequent drowning and death, mainly due to severe pain. It is also suggested that the death of these seabirds occurs acutely ( $<24$ hours), due to the digestion stage of the fish found in their gastrointestinal tracts (Hilton et al. 2000). The present report is the first to attribute the venomous toadfish $P$. porosissimus as the cause of death of adult and juvenile brown boobies ( $S$. leucogaster). Further studies should evaluate this negative relationship between fish and seabirds along the Brazilian coast.

\section{Author contributions}

Rachel Ann Hauser-Davis: Substantial contribution in the concept and design of the study; Contribution to data analysis and interpretation; Contribution to manuscript preparation; Contribution to critical revision, adding intellectual content.

Amanda Dias Tadeu: Substantial contribution in the concept and design of the study; Contribution to data collection; Contribution to data analysis and interpretation; Contribution to manuscript preparation; Contribution to critical revision, adding intellectual content.

Ana Carolina da Silva Scarelli: Substantial contribution in the concept and design of the study; Contribution to data collection; Contribution to data analysis and interpretation; Contribution to manuscript preparation; Contribution to critical revision, adding intellectual content.

Hassan Jerdy: Substantial contribution in the concept and design of the study; Contribution to data collection; Contribution to data analysis and interpretation; Contribution to manuscript preparation; Contribution to critical revision, adding intellectual content.

Eulogio Carvalho: Contribution to data collection; Contribution to data analysis and interpretation; Contribution to critical revision, adding intelectual content.

Sergio Carvalho Moreira: Contribution to data analysis and interpretation; Contribution to manuscript preparation; Contribution to critical revision, adding intellectual content.

Salvatore Siciliano: Substantial contribution in the concept and design of the study; Contribution to data collection; Contribution to data analysis and interpretation; Contribution to manuscript preparation; Contribution to critical revision, adding intellectual content.

\section{Conflict of interest}

The authors declare that they have no conflict of interest related to the publication of this manuscript.

\section{References}

ALVES, V.S., SOARES, A.B.A., COUTO, G.S., EFE, M.A. \& RIBEIRO, A.B.B. 2004. Aves marinhas de Abrolhos - Bahia, Brasil. In Aves marinhas e insulares Brasileiras: bioecologia econservação (J. O. Branco, ed.) UNIVALI, Itajaí, p.213-232.

BAUMGARTEN, M.M. 2003. Estudo Genético-Populacional em Atobás (Pelecaniformes, Aves) da Costa Brasileira. Universidade de São Paulo.

BENEMANN, V.R.F., KRÜGER, L., VALLS, F.C.L. \& PETRY, M. V. 2016. Evidence of an unreported negative effect of fisheries discards on seabirds: Death by choking on the Atlantic Midshipman, Porichthys porosissimus, in southern Brazil. Emu 116(1): 48-51.

COELHO, E.P., ALVES, V.S., SOARES, A.B.A., COUTO, G.S., EFE, M.A., RIBEIRO, A.B.B., VIELLIARD, J. \& GONZAGA, L.P. 2004. O Atobámarrom (Sula leucogaster) na ilha de CaboFrio, Arraial do Cabo, Rio de Janeiro, Brasil. In Aves marinhas e insulares Brasileiras: bioecologia e conservação (J. O. Branco, ed.) UNIVALI, Itajaí, p.233-254.

COLLETTE, B. \& RUSSO, J. 1981. A Revision of the Scaly Toadfishes, Genus Batrachoides, with Descriptions of Two New Species from the Eastern Pacific. Bull. Mar. Sci. 31(2):197-233.

CORMIER, M.J., CRANE, J.M. \& NAKANO, Y. 1967. Evidence for the identity of the luminescent systems of Porichthys porosissimus (fish) and Cypridina hilgendorfii (crustacean). Biochem. Biophys. Res. Commun. 29(5):747-752.

CUNHA, L.S.T., TORRES, J.P.M., MUÑOZ-ARNANZ, J. \& JIMÉNEZ, B. 2012. Evaluation of the possible adverse effects of legacy persistent organic pollutants (POPs) on the brown booby (Sula leucogaster) along the Brazilian coast. Chemosphere 87(9):1039-1044.

FIGUEIREDO, I. L. \& MENEZES, N.A. 1980. Manual de Peixes Marinhos do Sudeste do Brasil. 1I. Teleostei (2). Universidade de São Paulo, São Paulo.

FIGUEIREDO, J.L. de, SANTOS, A.P. dos, YAMAGUTI, N., BERNARDES, R.A. \& ROSSI-WONGTSCHOWSKI, C.L.D.B. 2002. Peixes da zona econômica exclusiva da Região Sudeste-Sul do Brasil: Levantamento com Rede de Meia-Água. São-Paulo.

FIGUEIREDO, J.L. \& MENEZES, N.A. 1978. Manual de peixes marinhos do sudeste do Brasil. 11. Teleostei (1). Universidade de São Paulo, Museu de Zoologia. 110p.

FISHBASE. 2019. Porichthys porosissimus (Cuvier, 1829). Available at: https:// www.fishbase.se/summary/Porichthys-porosissimus

FLOETER, S.R., ROCHA, L. a, FERREIRA, C.E.L., RANGEL, C. a \& FEITOZA, B.M. 2003. Brazilian reef fish fauna: Checklist and remarks. Brazilian Reef Fish Proj.

VAN FRANEKER, J.A. 2004. Save the North Sea Fulmar-Litter -EcoQO Manual Part 1: Collection and dissection procedures. Wageningen: Alterra - Report 672.

GREENFIELD, D.W., WINTERBOTTOM, R. \& COLLETTE, B.B. 2008. Review of the toadfish genera (Teleostei: Batrachoididae). Proc. Calif. Acad. Sci. 59(15):665-710.

HILTON, G.M., FURNESS, R.W. \& HOUSTON, D.C. 2000. A comparative study of digestion in North Atlantic seabirds. J. Avian Biol. 31(1):36-46.

JUNQUEIRA, M.E.P., GRUND, L.Z., ORII, N.M., SARAIVA, T.C., DE MAGALHÃES LOPES, C.A., LIMA, C. \& LOPES-FERREIRA, M. 2007. Analysis of the inflammatory reaction induced by the catfish (Cathorops spixii) venoms. Toxicon 49(7):909-919.

LANE, E.D. 1967. A study of the Atlantic midshipmen, Porichthys porosissimus, in the vicinity of Port Aransas, Texas. Contrib. Mar. Sci. 121-53.

LOPES-FERREIRA, M., RAMOS, A.D., MARTINS, I.A., LIMA, C., CONCEIÇÃO, K. \& HADDAD, V. 2014. Clinical manifestations and experimental studies on the spine extract of the toadfish Porichthys porosissimus. Toxicon $8628-39$. 
MAGALHÃES, K.W., LIMA, C., PIRAN-SOARES, A.A., MARQUES, E.E., HIRUMA-LIMA, C.A. \& LOPES-FERREIRA, M. 2006. Biological and biochemical properties of the Brazilian Potamotrygon stingrays: Potamotrygon cf. scobina and Potamotrygon gr. orbignyi. Toxicon 47(5):575-583.

MONTEIRO DOS SANTOS, J., CONCEIÇÃO, K., SEIBERT, C.S., MARQUES, E.E., ISMAEL SILVA, P., SOARES, A.B., LIMA, C. \& LOPES-FERREIRA, M. 2011. Studies on pharmacological properties of mucus and sting venom of Potamotrygon cf. henlei. Int. Immunopharmacol. 11(9):1368-1377.

NAKAMURA, I., INADA, T., TAKEDA, M. \& HATANAKA, H. 1986. Important fishes trawled off Patagonia. Japan Marine Fishery Resource Research Center, Tokyo.

NELSON, I.B. 1978. The Sulidae - Gannets and Bobbies. Oxford University Press, Oxford.

SCHREIBER, E. \& NORTON, R. 2002. Brown booby: Sula leucogaster. Birds North Am. 17(1):1-26.

SMITH, W.L. \& WHEELER, W.C. 2006. Venom evolution widespread in fishes: A phylogenetic road map for the bioprospecting of piscine venoms. J. Hered. 97(3):206-217.
SOSA-ROSALES, J.I., D’SUZE, G., SALAZAR, V., FOX, J. \& SEVCIK, C. 2005. Purification of a myotoxin from the toadfish Thalassophryne maculosa (Günter) venom. Toxicon 45(2):147-153.

VIANNA, M., TOMAS, A.R.G. \& VERANI, J.R. 2000. Aspects of the biology of the Atlantic Midshipman, Porichthys porosissimus (Teleostei, Batrachoididae): an important by-catch species of shrimp trawling off southern Brazil. Rev. Bras. Oceanogr. 48(2):131-140.

WALKER, H.J. \& ROSENBLATT, R.H. 1988. Pacific Toadfishes of the Genus Porichthys (Batrachoididae) with Descriptions of Three New Species. Copeia 4887-904.

WORK, T.M. 2000. Avian necropsy manual for biologists in remote refuges. U.S. Geological Survey National Wildlife Health Center, Hawaii.

Received: 10/09/2020

Revised: 21/11/2020

Accepted: 06/12/2020

Published online: 25/06/2021 